University of Nebraska - Lincoln

DigitalCommons@University of Nebraska - Lincoln

$10-2009$

\title{
The receptor mechanisms underlying the disruptive effects of haloperidol and clozapine on rat maternal behavior: A double dissociation between dopamine $\mathrm{D}_{2}$ and $5-\mathrm{HT}_{2 \mathrm{~A} / 2 \mathrm{C} \text { receptors }}$
}

\author{
Changjiu Zhao \\ University of Nebraska-Lincoln \\ Ming Li \\ University of Nebraska-Lincoln, mli2@unl.edu
}

Follow this and additional works at: https://digitalcommons.unl.edu/psychfacpub

Part of the Psychiatry and Psychology Commons

Zhao, Changjiu and Li, Ming, "The receptor mechanisms underlying the disruptive effects of haloperidol and clozapine on rat maternal behavior: A double dissociation between dopamine $\mathrm{D}_{2}$ and $5-\mathrm{HT}_{2} \mathrm{~A} / 2 \mathrm{C}$ receptors" (2009). Faculty Publications, Department of Psychology. 587.

https://digitalcommons.unl.edu/psychfacpub/587

This Article is brought to you for free and open access by the Psychology, Department of at DigitalCommons@University of Nebraska - Lincoln. It has been accepted for inclusion in Faculty Publications, Department of Psychology by an authorized administrator of DigitalCommons@University of Nebraska - Lincoln. 


\title{
The receptor mechanisms underlying the disruptive effects of haloperidol and clozapine on rat maternal behavior: A double dissociation between dopamine $\mathrm{D}_{2}$ and $5-\mathrm{HT}_{2 \mathrm{~A} / 2 \mathrm{C}}$ receptors
}

\author{
Changjiu Zhao and Ming Li \\ Department of Psychology, University of Nebraska-Lincoln, 238 Burnett Hall, Lincoln, NE 68588-0308, USA \\ Corresponding author - M. Li, tel 402 472-3144, fax 402 472-4637, email mliz@unl.edu
}

\begin{abstract}
Many antipsychotic drugs disrupt active components of maternal behavior such as pup approach, pup retrieval and nest building at clinically relevant doses in postpartum female rats. However, the neurochemical mechanisms underlying such a disruptive effect remain to be determined. This study examined the neurochemical mechanisms that mediate the disruptive effects of haloperidol (a typical antipsychotic) and clozapine (an atypical antipsychotic) on rat maternal behavior. Postpartum rats were administered with haloperidol $(0.2 \mathrm{mg} / \mathrm{kg}, \mathrm{sc})$ or clozapine $(10.0 \mathrm{mg} / \mathrm{kg}$, sc) together with either vehicle (saline or water), quinpirole (a selective dopamine $\mathrm{D}_{2} / \mathrm{D}_{3}$ agonist, 0.5 or $1.0 \mathrm{mg} / \mathrm{kg}, \mathrm{sc}$ ), or 2,5-dimethoxy-4-iodo-amphetamine (DOI, a selective $5-\mathrm{HT}_{2 \mathrm{~A} / 2 \mathrm{C}}$ agonist, 1.0 or $2.5 \mathrm{mg} / \mathrm{kg}, \mathrm{sc}$ ), and their maternal behaviors were tested at different time points before and after drug administration. Haloperidol and clozapine treatment disrupted pup approach, pup retrieval, pup licking and nest building. Pretreatment of quinpirole, but not DOI, dose-dependently reversed the haloperidol-induced disruptions. In contrast, pretreatment of DOI, but not quinpirole, dose-dependently reversed the clozapineinduced disruptions. Quinpirole pretreatment even exacerbated the clozapine-induced disruption of pup retrieval and nest building. These findings suggest a double dissociation mechanism underlying the disruption of haloperidol and clozapine on rat maternal behavior. Specifically, haloperidol disrupts maternal behavior primarily by blocking dopamine $\mathrm{D}_{2}$ receptors, whereas clozapine exerts its disruptive effect primarily by blocking the $5-\mathrm{HT}_{2 \mathrm{~A} / 2 \mathrm{C}}$ receptors. Our findings also suggest that 5 -HT receptors are involved in the mediation of rat maternal behavior.
\end{abstract}

Keywords: Haloperidol, Clozapine, Dopamine $\mathrm{D}_{2} / \mathrm{D}_{3}$ receptor, Quinpirole, $5-\mathrm{HT}_{2 \mathrm{~A} / 2 \mathrm{C}}$ receptor, DOI, Rat maternal behavior

\section{Introduction}

Maternal behavior in rats is a complex behavior that shares many features with human mothering behavior (Fleming and Corter, 1988). It is naturally expressed for the first time with the birth of the first litter. Within hours of parturition, the mother rat reconstructs the nest, retrieves the displaced pups, gathers them together in the nest site and adopts a nursing posture over the pups to permit suckling (Dollinger et al., 1980; Rosenblatt and Lehrman, 1963). The mother rat (dam) continues to exhibit maternal behavior (pup licking, pup retrieval, nest building and nursing) over the subsequent 3-week period, although as the pups mature, the intensity and quality of her behavior changes (Galef, 1981; Rosenblatt and Lehrman, 1963).

In recent years, we have used the rat maternal behavior as an ecologically relevant model to investigate the behavioral mechanisms of action of antipsychotic drugs and attempted to capture the possible side effects of antipsychotic medications on human parental behaviors. We and others have shown that clinically comparable doses of haloperidol (HAL), clozapine (CLZ), risperidone and quetiapine $\left(\sim 50 \%-70 \%\right.$ dopamine $\mathrm{D}_{2}$ occupancy) disrupt active components of rat maternal behavior, such as pup retrieval, pup licking and nest building (Li et al., 2004; Stern and Taylor, 1991; Stern and Keer, 1999; Zhao and Li, 2009). HAL causes a prolonged disruption (up to $6 \mathrm{~h}$ ), whereas CLZ and other atypical antipsychotics induce an early onset but transient disruption (less than $6 \mathrm{~h}$ ). Novel antipsychotics such as amisulpride and aripiprazole also exhibit a certain degree of inhibition on active maternal responses in a dose-dependent fashion ( $\mathrm{Li}$ et al., 2005a). Chronic treatment with HAL or olanzapine via minipumps or repeated daily injections significantly inhibits rat active maternal responses as well ( $\mathrm{Li}$ et al., 2005b). It seems that antipsychotic-induced inhibition on pup retrieval, pup licking and nest building may be an inherent feature of all currently available antipsychotics ( $\mathrm{Li}$ et al., 2004, 2005a; Silva et al., 2001; Stern and Taylor, 1991; Stern and Keer, 1999; Zhao and Li, 2009). Our recent work further identifies that sedation and suppression of maternal motivation are two important behavioral mechanisms underlying the disruptive effects of antipsychotic treatment on maternal behavior (Zhao and Li, 2009).

The present study investigated the neurochemical basis of antipsychotic-induced disruptive effects on rat maternal behavior. For typical antipsychotics, it is generally assumed that they disrupt maternal behavior by blocking dopamine $\mathrm{D}_{2}$ recep- 
tors because they are primarily dopamine $\mathrm{D}$ antagonists (Dragunow et al., 1990; Seeman et al., 1976), and because apomorphine, a dopamine receptor agonist, can reverse the inhibitory effects of haloperidol (Giordano et al., 1990). However, solid evidence demonstrating that typical antipsychotics do act through this specific $\mathrm{D}_{2}$ mechanism is still lacking. For atypical antipsychotics (e.g., clozapine, olanzapine), because they generally have multiple-receptor binding profiles (Meltzer, 1989; Miyamoto et al., 2005), it is hard to pinpoint their exact neurochemical mechanisms. Most atypical antipsychotics possess a much more potent antagonism on the 5 - $\mathrm{HT}_{2}$ receptor in addition to relatively weak antagonism on $\mathrm{D}_{2}$ receptor (Meltzer et al., 2003). It is thus possible that the disruptive effects of atypical antipsychotics on maternal behavior could be attributed to their action on $\mathrm{D}_{2}$ receptor alone (Kapur and Seeman, 2001) or to its dual action on both $5-\mathrm{HT}_{2}$ and $\mathrm{D}_{2}$ receptors (Meltzer et al., 1989a, 1989b) or on other receptors.

In the present study, we administered quinpirole, a selective $\mathrm{D}_{2} / \mathrm{D}_{3}$ dopaminergic receptor agonist or 2,5-dimethoxy-4-iodoamphetamine (DOI), a selective $5-\mathrm{HT}_{2 \mathrm{~A} / 2 \mathrm{C}}$ serotonergic receptor agonist together with HAL $(0.2 \mathrm{mg} / \mathrm{kg})$ or CLZ (10.0 mg/kg) to postpartum rats. We examined which of these two agonists was able to reverse the disruptive effects induced by HAL or CLZ. We hypothesized that quinpirole, but not DOI, would be able to reverse the HAL-induced disruption on maternal behavior and may also be effective in alleviating the CLZ-induced disruption to some extent. We had no prior conviction regarding the effect of DOI due to lack of sufficient evidence in the literature on the role of serotonin in maternal behavior (Numan and Insel, 2003).

\section{Materials and methods}

\subsection{Subjects}

Animals were naive pregnant female Sprague-Dawley rats (912 weeks old at the start of pregnancy) purchased from Charles River Inc. (Portage, MI). Upon arrival to our animal facility, the rats were between gestational days 13-15. Each subject was housed individually in $48.3 \mathrm{~cm} \times 26.7 \mathrm{~cm} \times 20.3 \mathrm{~cm}$ transparent polycarbonate cage lined with aspen shavings in a colony on a 12-h light/dark cycle (lights on at 6:30 AM). All behavioral tests were performed in the light phase between 9:00 AM and 4:00 PM. The colony was maintained under standard vivarium conditions with an ambient temperature of $23{ }^{\circ} \mathrm{C}$, relative humidity of $55-60 \%$. Standard laboratory rat chow and water were available adlibitum. All animal procedures were approved by the University of Nebraska Institutional Animal Care and Use Committee.

\subsection{Drugs and choices of doses}

HAL (5.0 mg/ml ampoules, Sicor Pharmaceuticals, Inc, Irvine, CA) was diluted with sterile water. CLZ (a gift from NIMH drug supply program) was dissolved in $1.0 \%$ glacial acetic acid in distilled water. Quinpirole (QUI) and DOI (RBI-Sigma, Natick, MA) were dissolved in $0.9 \%$ saline. HAL (o.2 $\mathrm{mg} / \mathrm{kg}$ ), CLZ (10.0 mg/kg), QUI (o.5 or 1.0 mg/kg), DOI (1.0 or $2.5 \mathrm{mg} / \mathrm{kg}$ ) and vehicle (water or saline) were all administered subcutaneously in a volume of $1.0 \mathrm{ml} / \mathrm{kg}$ body weight. Choices of drug doses for HAL and CLZ were based on our previous studies showing that, at these doses, HAL and CLZ effectively disrupt active maternal behaviors in rats (Li et al., 2004; Zhao and Li, 2009). The doses of QUI were chosen based on our preliminary study showing that $1.0 \mathrm{mg} / \mathrm{kg}$ of QUI improved the HAL's disruption on pup retrieval. DOI doses were chosen on the basis of reports showing that DOI at these doses potentiates the effects of amphetamine on dopamine release in the striatum, medial prefrontal cortex and nucleus accumbens (Ichikawa and Meltzer, 1995; Kuroki et al., 2003) and blocks the CLZ-induced dopamine release in the medial prefrontal cortex (Ichikawa et al., 2001).

\subsection{Basic experimental procedure}

Starting 2 or 3 days prior to the first possible expected parturition date, the subjects were monitored every morning for signs of parturition. Once the dam was found with pups in the morning (that day was designated as Day 1 postpartum), the mother was transferred into a clean cage with wood shavings for bedding. Two shredded paper towels were also provided for nesting material. The litter was culled to 8 pups (4 males and 4 females with the most visible milk bands). Maternal behavior tests were conducted on one day between Days 6 and 8 postpartum.

\subsection{Maternal behavior test}

The basic procedure was similar to what has been described in Zhao and Li (2009). Using a laptop computer with an event recording program (JWatcher, http://www.jwatcher.ucla.edu/), we recorded various components of maternal behavior in an 8-min testing session at different time points before and after drug administration. Each test started by removing the 8 pups from the dam and destroying the nest. Ten seconds later, the pups were returned to the corner of the cage diagonal to the nest site or dam sleeping corner. When the subject picked up a pup in her mouth and carried it back to the nest site, it was referred to as a successful pup retrieval. The total number of pups retrieved was recorded. Approach latency was defined as the time taken for mother rats to approach and sniff the pups from the reunion. First and last pup retrieval latency was defined as the time elapsed from the first pup approach to the retrieval of the first and eighth pup into the nest, respectively. A score of $480 \mathrm{~s}$ was assigned to non-responders who did not approach or retrieve the testing pups at all. The occurrence of other behaviors was also recorded, including pup nursing behavior (a rat positioning herself over the pups with legs splayed to accommodate the pups, including hover, high and low crouching over postures), pup licking (a female rat placing its tongue on the anogenital area and the rest of a pup's body), nest building (a rat picking up nesting material in her mouth and transporting it back to the nest site or pushing the material with her forepaws toward the nest site). At the conclusion of the test, any unretrieved pups were returned to the nest site.

2.4.1. Experiment 1. Effects of pretreatment with quinpirole or DOI on haloperidol-induced maternal behavior deficits in rats Forty-four postpartum rats were randomly assigned to one of the following six groups: VEH+VEH $(n=4$, sterile water or saline), VEH+HAL $(n=8)$, QUI-o.5+HAL $(n=8)$, QUI-1.o+HAL $(n=8)$, DOI-1.0+HAL $(n=8)$, and DOI-2.5+HAL $(n=8)$. On the drug test day ( 1 day on either Postpartum Day 6,7 , or 8 ), all subjects were tested 5 times at different time points before and after drug administrations, with the first maternal behavior test starting at $30 \mathrm{~min}$ prior to the HAL or vehicle injection (i.e., baseline) and the other tests occurring at 30,60, 120 and 240 min after HAL or vehicle injection. QUI, DOI or vehicle was injected s.c. twice with the first injection at $10 \mathrm{~min}$ before and the second at $50 \mathrm{~min}$ after the HAL or vehicle injection. We adopted such an injection strategy because our preliminary data showed that injection of QUI at 10 min prior to the administration of HAL could optimally reverse its disruption on pup retrieval. Also, agonists were injected twice separately on the basis of their relatively short duration of action and rapid peak plasma concentrations (Deutch and Duman, 1996; Whitaker and Lindstrom, 1987).

2.4.2. Experiment 2. Effects of pretreatment with quinpirole or DOI on clozapine-induced maternal behavior deficits in rats

The basic procedure was identical to that of Experiment 1 with the exception that CLZ was tested in this experiment instead of haloperidol. Forty-four postpartum rats were randomly assigned to one of the following six groups and their maternal be- 
haviors were tested: VEH+VEH ( $n=4$, sterile water or saline), VEH+CLZ $(n=8)$, QUI-o.5+CLZ $(n=8)$, QUI-1.o+CLZ $(n=8)$, DOI-1.0+CLZ $(n=8)$, and DOI-2.5+CLZ $(n=8)$.

\subsection{Data analysis}

With the exception of latency data, various measurements of maternal behavior were expressed as mean \pm SEM. To increase statistical power, we combined the two vehicle control groups from Experiments 1 and 2 into a single group since they did not differ significantly on any measure (Independent-Samples $T$ test or Mann-Whitney $U$ test, all $p s>0.10)$. Data were analyzed using a factorial repeated measures analysis of variance (ANOVA) with the between-subjects factor being the treatment groups (e.g. saline, HAL) and the within-subjects factor being test time points (baseline, 30, 60, 120 and 240 min post-injection). Group differences at different time points were further analyzed using simple main effect test (one-way ANOVA) followed by Turkey's HSD post hoc tests where appropriate.

For the latency data, because they were not normally distributed (e.g. the cut-off time assigned $480 \mathrm{~s}$ for the latency data), these data were expressed as median \pm interquartile range. Nonparametric Kruskal-Wallis test was used for analyzing the differences among the treatment groups. Once the overall significant effects were determined, two-group comparisons were performed using Mann-Whitney $U$ test. A conventional two-tailed level of significance at the 0.05 level was required.

\section{Results}

\subsection{Experiment 1. Effects of pretreatment with QUI or DOI on haloperidol-induced maternal behavior deficits}

\subsubsection{Haloperidol treatment disrupted various components of ma- ternal behavior}

Consistent with our previous findings (Li et al., 2004; Zhao and Li, 2009), a single injection of HAL significantly disrupted various active components of maternal behavior (pup retrieval, pup licking, nest building, but not pup nursing). Rats treated with HAL took a much longer time to initiate contact with pups and retrieve their pups into the nest sites (Table 1) and retrieved fewer pups at the 30, 60, 120 and 240 min test points (Figure 1 and Figure $2 \mathrm{~A})(0.001<$ all $p \mathrm{~s}<0.05)$ compared to the vehicle-treated rats. They also spent less time licking their pups at the 30, 60 and 120 min test points and rebuilding the nest at the $30,60,120$ and 240 min test points ( Figure $1 \&$ Figure 2 B,C) (o.oo1 < all ps < 0.05). However, HAL treatment had no significant effect on nursing activity ( Figure $1 \&$ Figure $2 \mathrm{D}$ ).
3.1.2. QUI pretreatment dose-dependently improved the haloperidol-induced maternal behavior deficits

As can be seen in Table 1 and Figure $1 \mathrm{~A}-\mathrm{C}$, both doses of QUI improved the HAL-induced deficits in pup approach, pup retrieval, pup licking and nest building, as described below.

3.1.2.1. Latency to approach and retrieve pups. QUI shortened the HAL-induced increase in pup approach latency and the first and last pup retrieval latencies (Table 1). Both 0.5 and $1.0 \mathrm{mg} / \mathrm{kg}$ doses of QUI were effective in facilitating the HALtreated dams to initiate contact with their pups and completely restored such behavior to the normal level (e.g., VEH+VEH group) across the testing period. For the pup retrieval latency, it appeared that both doses of QUI shortened the time the HALtreated rats took to retrieve their first and last pups to the nest site and reinstated the first pup retrieval to the normal level at the 30,120 and 240 min test points post-injection.

3.1.2.2. Number of pups retrieved. Both 0.5 and $1.0 \mathrm{mg} / \mathrm{kg}$ of QUI increased the number of pups retrieved in the HAL-treated rats and restored it to the normal level at certain time points of testing. Repeated measures ANOVA revealed that there was a significant interaction between the treatment groups and time points $[F(20,168)=5.97, p<0.001]$, a significant main effect of treatment groups $[F(5,42)=26.30, p<0.001]$, and a significant effect of time points $[F(4,168)=35.22, p<0.001]$. One-way ANOVA and post hoc tests showed that the QUI-0.5+HAL group was significantly different from the VEH+HAL group at the 30 and 120 min time points (Figure $1 \mathrm{~A}, p<0.001$ for $30 \mathrm{~min}, p=0.022$ for $120 \mathrm{~min}$ ), whereas the QUI-1.O+HAL group differed from the VEH+HAL group at the 30, 120 and 240 min test points (Figure $1 \mathrm{~A}, p<0.001$ for 30 and $120 \mathrm{~min}, p=0.014$ for $240 \mathrm{~min}$ ). Further analysis showed that the reversing effect of $0.5 \mathrm{mg} / \mathrm{kg}$ of QUI reached the control level at the 30 and $120 \mathrm{~min}$ test points while the $1.0 \mathrm{mg} / \mathrm{kg}$ of QUI restored the CLZ-induced disruption to the normal level at the 30, 120 and 240 min test points when the two QUI+HAL groups were compared with the VEH+VEH control group (Figure $1 \mathrm{~A}$, all $p s>0.10$ ). It appears that the strongest reversal effect of QUI occurred 120 min after HAL administration (Figure $1 \mathrm{~A}$ ).

3.1.2.3. Pup licking. QUI produced a reversing effect on HALinduced pup licking deficit. Repeated measures ANOVA revealed a main effect of treatment groups $[F(5,42)=4.56, p=0.002]$, a significant effect of test time points $[F(4,168)=7.71, p<0.001]$, but no significant interaction between the two factors. One-way ANOVA and post hoc tests showed that both QUI groups differed significantly from the VEH+HAL group at the 120 min test point (Figure $1 \mathrm{~B}, p=0.045$ for QUI-0.5+HAL group, $p=0.042$ for QUI1.O+HAL group). Further analysis showed that the reversing effect

Table 1. Effects of pretreatment with quinpirole or DOI on pup approach latency and pup retrieval latency in postpartum female rats treated with haloperidol or vehicle.

\begin{tabular}{|c|c|c|c|c|c|c|c|c|c|c|c|c|c|c|c|c|}
\hline \multirow[t]{2}{*}{ Groups } & \multirow[t]{2}{*}{$N$} & \multicolumn{5}{|c|}{ Approach latency (s) } & \multicolumn{5}{|c|}{ First pup retrieval latency (s) } & \multicolumn{5}{|c|}{ Last pup retrieval latency (s) } \\
\hline & & Baseline & $30 \mathrm{~min}$ & $60 \mathrm{~min}$ & $120 \mathrm{~min}$ & $240 \mathrm{~min}$ & Baseline & $30 \mathrm{~min}$ & $60 \mathrm{~min}$ & $120 \mathrm{~min}$ & $240 \mathrm{~min}$ & Baseline & $30 \mathrm{~min}$ & $60 \mathrm{~min}$ & $120 \mathrm{~min}$ & $240 \mathrm{~min}$ \\
\hline VEH+VEH & 8 & $\begin{array}{l}2.1 \\
(2.0)\end{array}$ & $\begin{array}{l}1.2 \\
(0.7)\end{array}$ & $\begin{array}{l}1.5 \\
(1.2)\end{array}$ & $\begin{array}{l}1.5 \\
(0.8)\end{array}$ & $\begin{array}{l}1.9 \\
(4.6)\end{array}$ & $\begin{array}{l}2.8 \\
(87.0)\end{array}$ & $\begin{array}{l}2.0 \\
(0.9)\end{array}$ & $\begin{array}{l}2.6 \\
(1.4)\end{array}$ & $\begin{array}{l}2.1 \\
(0.7)\end{array}$ & $\begin{array}{l}1.9 \\
(0.5)\end{array}$ & $\begin{array}{l}38.3 \\
(104.0)\end{array}$ & $\begin{array}{l}22.6 \\
(9.7)\end{array}$ & $\begin{array}{l}23.9 \\
(7.7)\end{array}$ & $\begin{array}{l}21.7 \\
(9.8)\end{array}$ & $\begin{array}{l}24.0 \\
(14.4)\end{array}$ \\
\hline VEH+HAL & 8 & $\begin{array}{l}1.8 \\
(0.9)\end{array}$ & $\begin{array}{l}15.6^{a} \\
(106.9)\end{array}$ & $\begin{array}{l}87.5^{\mathrm{a}} \\
(311.7)\end{array}$ & $\begin{array}{l}45.4^{\mathrm{a}} \\
(224.6)\end{array}$ & $\begin{array}{l}23.2^{\mathrm{a}} \\
(135.1)\end{array}$ & $\begin{array}{l}11.7 \\
(100.8)\end{array}$ & $\begin{array}{l}480.0^{a} \\
(0.0)\end{array}$ & $\begin{array}{l}480.0^{a} \\
(0.0)\end{array}$ & $\begin{array}{l}480.0^{a} \\
(0.0)\end{array}$ & $\begin{array}{l}245.6^{\mathrm{a}} \\
(476.1)\end{array}$ & $\begin{array}{l}112.4 \\
(382.9)\end{array}$ & $\begin{array}{l}480.0^{a} \\
(0.0)\end{array}$ & $\begin{array}{l}480.0^{a} \\
(0.0)\end{array}$ & $\begin{array}{l}480.0^{a} \\
(0.0)\end{array}$ & $\begin{array}{l}480.0^{a} \\
(272.7)\end{array}$ \\
\hline QUI-0.5+HAL & 8 & $\begin{array}{l}1.4 \\
(0.8)\end{array}$ & $\begin{array}{l}2.2^{b} \\
(15.1)\end{array}$ & $\begin{array}{l}3.4^{b} \\
(26.9)\end{array}$ & $\begin{array}{l}2.6^{\mathrm{b}} \\
(5.6)\end{array}$ & $\begin{array}{l}8.8^{b} \\
(41.6)\end{array}$ & $\begin{array}{l}47 \cdot 4 \\
(89.6)\end{array}$ & $\begin{array}{l}4.0^{\mathrm{b}} \\
(35.7)\end{array}$ & $\begin{array}{l}480.0^{a} \\
(357.8)\end{array}$ & $\begin{array}{l}3 \cdot 3^{\mathrm{b}} \\
\left(35^{8.2}\right)\end{array}$ & $\begin{array}{l}3.3^{\mathrm{b}} \\
\left(35^{8.4}\right)\end{array}$ & $\begin{array}{l}141.0 \\
(289.1)\end{array}$ & $\begin{array}{l}75 \cdot 9^{a, b} \\
(55 \cdot 9)\end{array}$ & $\begin{array}{l}480.0^{a} \\
(241.2)\end{array}$ & $\begin{array}{l}285.4^{a} \\
(443.6)\end{array}$ & $\begin{array}{l}74.0^{\mathrm{a}, \mathrm{b}} \\
\left(35^{2.6}\right)\end{array}$ \\
\hline QUI-1.o+HAL & 8 & $\begin{array}{l}2.8 \\
(4.1)\end{array}$ & $\begin{array}{l}2.8^{b} \\
(7 \cdot 4)\end{array}$ & $\begin{array}{l}12.5^{\mathrm{b}} \\
(78.1)\end{array}$ & $\begin{array}{l}7 \cdot 7^{\mathrm{b}} \\
(24.5)\end{array}$ & $\begin{array}{l}5.6^{b} \\
(14.2)\end{array}$ & $\begin{array}{l}30.7 \\
(84.1)\end{array}$ & $\begin{array}{l}4.3^{b} \\
(12.0)\end{array}$ & $\begin{array}{l}247.1^{\mathrm{a}} \\
(474.9)\end{array}$ & $\begin{array}{l}3.1^{b} \\
(2.0)\end{array}$ & $\begin{array}{l}2.4^{b} \\
(0.7)\end{array}$ & $\begin{array}{l}152.3 \\
(260.0)\end{array}$ & $\begin{array}{l}105.7^{\mathrm{a}, \mathrm{b}} \\
(417.8)\end{array}$ & $\begin{array}{l}480.0^{a} \\
(284.9)\end{array}$ & $\begin{array}{l}145.9^{a, b} \\
(104.0)\end{array}$ & $\begin{array}{l}67.1^{\mathrm{a}, \mathrm{b}} \\
(45 \cdot 5)\end{array}$ \\
\hline DOI-1.o+HAL & 8 & $\begin{array}{l}1.3 \\
(0.7)\end{array}$ & $\begin{array}{l}13.1^{\mathrm{a}} \\
(29.5)\end{array}$ & $\begin{array}{l}115 \cdot 7^{\mathrm{a}} \\
(122.6)\end{array}$ & $\begin{array}{l}43.6^{a} \\
(52.2)\end{array}$ & $\begin{array}{l}30.6^{a} \\
(361.4)\end{array}$ & $\begin{array}{l}2.8 \\
(189.40\end{array}$ & $\begin{array}{l}293.6^{a} \\
(441.1)\end{array}$ & $\begin{array}{l}480.0^{a} \\
(0.0)\end{array}$ & $\begin{array}{l}480.0^{a} \\
(0.0)\end{array}$ & $\begin{array}{l}65.2^{\mathrm{a}} \\
(476.8)\end{array}$ & $\begin{array}{l}179.7 \\
(450.6)\end{array}$ & $\begin{array}{l}480.0^{a} \\
(0.0)\end{array}$ & $\begin{array}{l}480.0^{a} \\
(0.0)\end{array}$ & $\begin{array}{l}480.0^{a} \\
(0.0)\end{array}$ & $\begin{array}{l}480.0^{a} \\
(356.1)\end{array}$ \\
\hline DOI-2.5+HAL & 8 & $\begin{array}{l}2.0 \\
(5.9)\end{array}$ & $\begin{array}{l}49.3^{\mathrm{a}} \\
(107.8)\end{array}$ & $\begin{array}{l}480.0^{a, b} \\
(169.4)\end{array}$ & $\begin{array}{l}278.6^{\mathrm{a}} \\
(446.2)\end{array}$ & $\begin{array}{l}81.9^{a} \\
(216.1)\end{array}$ & $\begin{array}{l}3.1 \\
(15 \cdot 3)\end{array}$ & $\begin{array}{l}480.0^{a} \\
\text { (o.o) }\end{array}$ & $\begin{array}{l}480.0^{a} \\
(0.0)\end{array}$ & $\begin{array}{l}480.0^{a} \\
(0.0)\end{array}$ & $\begin{array}{l}480.0^{a} \\
(0.0)\end{array}$ & $\begin{array}{l}69.6 \\
(59.2)\end{array}$ & $\begin{array}{l}480.0^{a} \\
(0.0)\end{array}$ & $\begin{array}{l}480.0^{a} \\
(0.0)\end{array}$ & $\begin{array}{l}480.0^{a} \\
(0.0)\end{array}$ & $\begin{array}{l}480.0^{a} \\
(0.0)\end{array}$ \\
\hline
\end{tabular}

Data are represented as median \pm interquartile range.

a. $p<0.05$ relative to the $\mathrm{VEH}+\mathrm{VEH}$ group; $\mathrm{b} . p<0.05$ relative to the $\mathrm{VEH}+\mathrm{HAL}$ group 

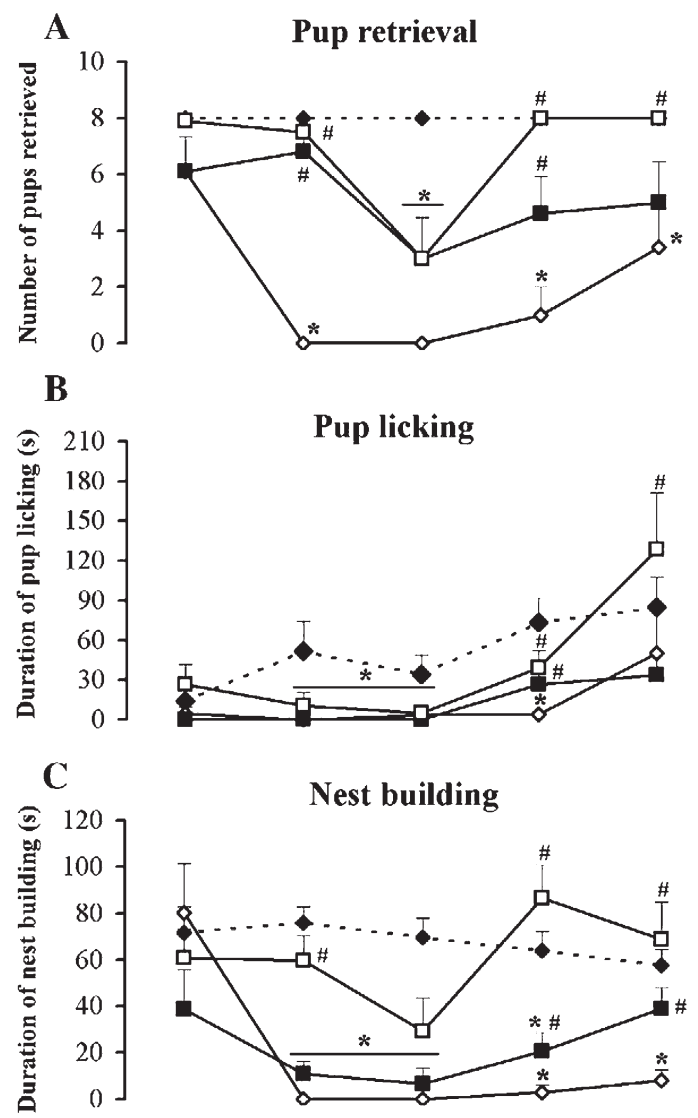

D

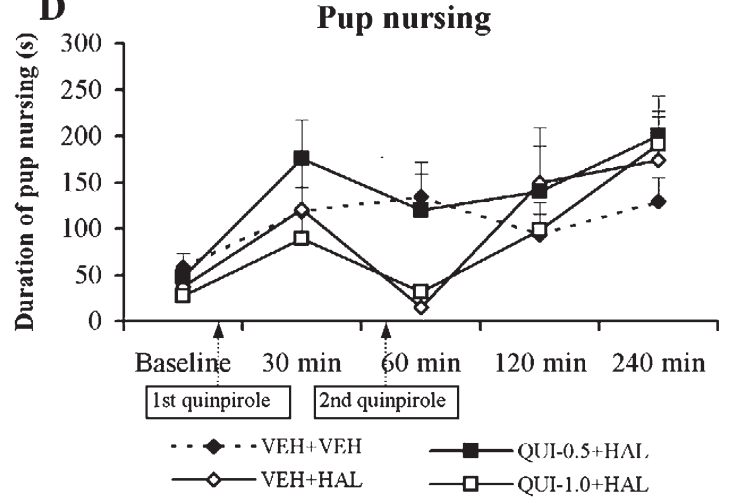

Figure 1. The time course of effects of the dopamine $\mathrm{D}_{2} / \mathrm{D}_{3}$ receptor agonist quinpirole on various HAL-induced maternal behavior deficits in postpartum female rats. Pup retrieval (A), pup licking (B), nest building (C) and pup nursing (D) were tested at baseline, 30, 6o, 120 and $240 \mathrm{~min}$ after injection of HAL or vehicle. HAL disrupted all the active maternal behaviors tested $(\mathrm{A}-\mathrm{C})$, but had no significant effect on pup nursing (D). Both 0.5 and $1.0 \mathrm{mg} / \mathrm{kg}$ of quinpirole improved the maternal behavior deficits induced by HAL in a dose-dependent fashion (A-C). Data were represented as mean + SEM. * $p<0.05$ versus VEH+VEH control; \# $p<0.05$ versus VEH+HAL group.

reached the normal level when the two QUI+HAL groups were compared to the VEH+VEH control group (Figure $1 \mathrm{~B}, p=0.85$ for QUI-0.5+HAL group, $p=0.95$ for QUI-1.0+HAL group).

3.1.2.4. Nest building. Similar to the effect on pup retrieval and pup licking, both doses of QUI significantly improved the HALinduced disruption of nest building activity. Repeated measures ANOVA revealed a significant interaction between the two factors $[F(20,168)=6.18, p<0.001]$, a significant main effect of treatment groups $[F(5,42)=17.52, p<0.001]$, and a significant effect of test-
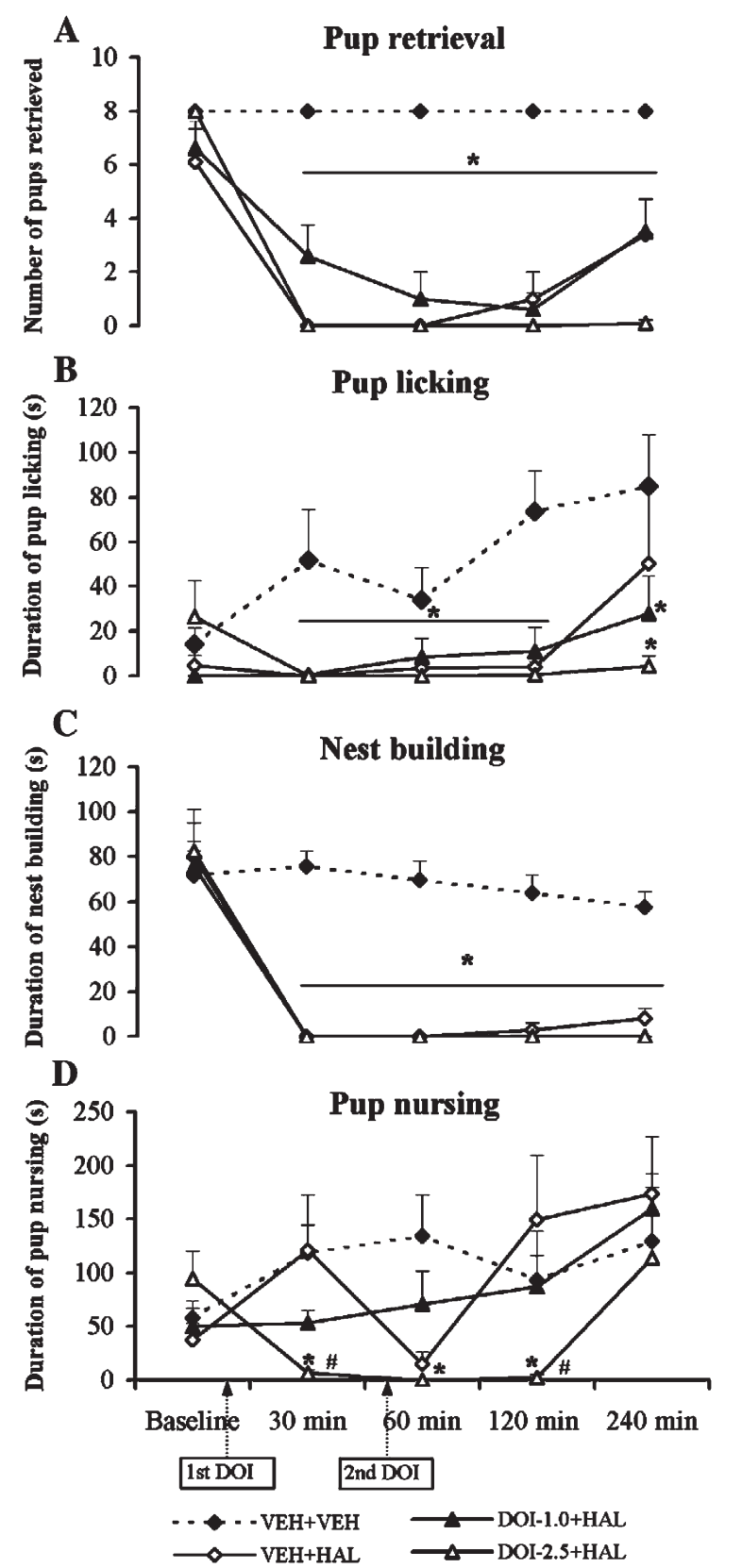

Figure 2. The time course of effects of the $5-\mathrm{HT}_{2 \mathrm{~A} / 2 \mathrm{C}}$ receptor agonist DOI on various HAL-induced maternal behavior deficits in postpartum female rats. Pup retrieval (A), pup licking (B), nest building (C) and pup nursing (D) were tested at baseline, 30, 60, 120 and $240 \mathrm{~min}$ after injection of HAL or vehicle. HAL disrupted all the active maternal behaviors tested $(\mathrm{A}-\mathrm{C})$, but had no significant effect on pup nursing (D). Neither 1.0 nor $2.5 \mathrm{mg} / \mathrm{kg}$ of DOI rescued the HAL-induced deficits on active maternal behaviors $(\mathrm{A}-\mathrm{C})$, but $2.5 \mathrm{mg} / \mathrm{kg}$ of DOI further suppressed nursing activity in HAL-treated dams (D). Data were represented as mean + SEM. ${ }^{*} p<0.05$ versus VEH+VEH control; ${ }^{\#} p<0.05$ versus VEH+HAL group.

ing time $[F(4,168)=35.95, p<0.001]$. One-way ANOVA and post hoc tests showed that the QUI-0.5+HAL group was significantly different from the VEH+HAL group at the 120 and 240 min test points (both $p s=0.021$ ), whereas the QUI-1.0+HAL group differed significantly from the VEH+HAL group at the 30, 120 and $240 \mathrm{~min}$ test points post-injection (Figure $1 \mathrm{C}$, all $p \mathrm{~s}<0.001$ ). In particular, although both doses of QUI reversed the disruptive effect of HAL at the $120 \mathrm{~min}$ test point, only $1.0 \mathrm{mg} / \mathrm{kg}$ of QUI was capable of improving it to the normal level when compared to the VEH+VEH group (Figure $1 C, p=0.34$ ). 
3.1.2.5. Pup nursing. As can be seen in Figure $1 \mathrm{D}$, QUI pretreatment had no significant effect on pup nursing. Repeated measures ANOVA revealed a significant interaction between the two factors $[F(20,168)=2.14, p=0.005]$, a significant main effect of treatment groups $[F(5,42)=4.66, p=0.002]$, and a significant effect of testing time $[F(4,168)=10.53, p<0.001]$. Post hoc tests showed that both QUI groups were not significantly different from the VEH+HAL group (both $p s>0.10$ ).

\subsubsection{DOI pretreatment failed to improve the haloperidol-induced} maternal behavior deficits

Both 1.0 and $2.5 \mathrm{mg} / \mathrm{kg}$ of DOI failed to improve the HAL-induced disruption on pup approach and pup retrieval, as evidenced by no significant improvement in the approach latency nor in first and last pup retrieval latency (Table 1) when the two DOI+HAL groups were compared to the VEH+HAL group. Rather, $2.5 \mathrm{mg} / \mathrm{kg}$ of DOI further exacerbated the HAL-induced disruption on the approach latency at the 60 min test point (Table $1, p=0.005$ ). Post hoc tests on the number of pups retrieved, pup licking and nest building revealed that there was no significant difference between the two DOI+HAL groups and the VEH+HAL group. For pup nursing, one-way ANOVA and post hoc tests indicated that the DOI-2.5+HAL group showed an even more suppressed nursing duration at the 30 and 120 min test points compared to the VEH+HAL group $(p=0.048$ for $30 \mathrm{~min}$, $p=0.041$ for $120 \mathrm{~min}$ ) (Figure 2D). The DOI-1.0+HAL group did not differ significantly from the VEH+HAL group across the testing period.

\subsection{Experiment 2. Effects of pretreatment with QUI or DOI on clozapine-induced maternal behavior deficits}

\subsubsection{Clozapine treatment impaired various components of maternal behavior}

Consistent with our previous findings (Li et al., 2004; Zhao and $\mathrm{Li}$, 2009), the present study showed that a single injection of CLZ significantly disrupted various active components of maternal behavior and maintained such a disruptive effect for about $2 \mathrm{~h}$. In comparison with the vehicle-treated ones, rats treated with CLZ took a much longer time to approach and retrieve their first pups into the nest sites (Table 2) at the 30, 6o and $120 \mathrm{~min}$ test points $(0.001<$ all $p s<0.01)$ and took longer to bring the last pups into the nest with less pups retrieved across the testing period (Table 2, Figure 3 \& Figure $4 \mathrm{~A})(0.001<$ all $p s<0.05)$. They also spent less time on pup licking, nest building and pup nursing at the 30, 6o and 120 min test points ( Figure 3 and Figure 4B,C,D) (all ps < 0.05).

\subsubsection{QUI pretreatment failed to improve the clozapine-induced maternal behavior deficits}

In contrast to its effects on HAL-induced maternal behavior deficits, both doses of QUI had little effect on the CLZ-induced disruptions of pup approach, pup retrieval latency (Table 2), the number of pups retrieved and nest building (Figure $3 \mathrm{~A}, \mathrm{C}$ ). Contrarily, QUI further potentiated the disruptive effect on these behaviors (Table 2, Figure 3A,C). Repeated measures ANOVA on the number of pups retrieved and nest building revealed a significant interaction between the treatment groups and test time points [the number of pups retrieved: $F(20,168)=9.56, p<0.001$; nest building: $F(20,168)=2.77, p<0.001]$, a significant main effect of treatment groups [the number of pups retrieved: $F(5,42)=\mathbf{2 0 . 4 1}$, $p<$ o.oo1; nest building: $F(5,42)=13.61, p<0.001$, and a significant effect of test time points [the number of pups retrieved: $F$ ( 4 , $168)=61.43, p<$ o.oo1; nest building: $F(4,168)=38.33, p<0.001]$. One-way ANOVA and post hoc tests showed that the QUI1.o+CLZ group differed significantly from the VEH+CLZ group in the number of pups retrieved and the duration of nest building at the 240 min test point (Figure $3 A, C, p=0.001$ for the number of pups retrieved, $p=0.007$ for the nest building), while the QUI$0.5+C L Z$ group differed from the $\mathrm{VEH}+\mathrm{CLZ}$ group in nest building at the 240 min test point (Figure ${ }_{3} C, p=0.026$ ). QUI pretreatment also did not improve the CLZ-induced deficits in pup licking and pup nursing activities (Figure $3 \mathrm{~B}, \mathrm{D}$ ) at any test points. Repeated measures ANOVA on pup licking and pup nursing revealed a significant interaction between the two factors [pup licking: $F$ (20, $168)=1.68, p=0.04$; pup nursing: $F(20,168)=2.05, p=0.007]$, a significant main effect of treatment groups [pup licking: $F$ (5, $42)=4.47, p=0.002$; pup nursing: $F(5,42)=5.52, p=0.001]$, and a significant effect of test time points [pup licking: $F(4,168)=8.02$, $p<$ o.ool; pup nursing: $F(4,168)=6.72, p<0.001]$. Post hoc tests on pup licking and pup nursing revealed that there was no significant difference between the two QUI+CLZ groups and the VEH+CLZ group.

3.2.3. DOI pretreatment dose-dependently reversed the clozapineinduced maternal behavior deficits

As shown in Table 2 and Figure 4A,B, pretreatment of both doses of DOI (1.0 and $2.5 \mathrm{mg} / \mathrm{kg}$ ) significantly improved the CLZ-induced disruption on pup approach, pup retrieval, and pup licking. However, the reversing effect of DOI on CLZ-induced disruption of nest building and pup nursing was not apparent (Figure $\left.{ }_{4} \mathrm{C}, \mathrm{D}\right)$.

3.2.3.1. Latency to approach and retrieve pups. As shown in Table 2, both 1.0 and $2.5 \mathrm{mg} / \mathrm{kg}$ of DOI shortened the prolonged approach latency induced by CLZ when the two DOI+CLZ groups were compared to the $\mathrm{VEH}+\mathrm{CLZ}$ group and restored it to the normal level compared to the $\mathrm{VEH}+\mathrm{VEH}$ group at the 30,60 and 120 min test points $(0.001<$ all $p s<0.01)$. It also reduced the CLZ-induced deficits of the first pup retrieval and restored it to

Table 2. Effects of pretreatment with quinpirole or DOI on pup approach latency and pup retrieval latency in postpartum female rats treated with clozapine or vehicle.

\begin{tabular}{|c|c|c|c|c|c|c|c|c|c|c|c|c|c|c|c|c|}
\hline \multirow[t]{2}{*}{ Groups } & \multirow[t]{2}{*}{$N$} & \multicolumn{5}{|c|}{ Approach latency (s) } & \multicolumn{5}{|c|}{ First pup retrieval latency (s) } & \multicolumn{5}{|c|}{ Last pup retrieval latency (s) } \\
\hline & & Baseline & $30 \mathrm{~min}$ & $60 \mathrm{~min}$ & $120 \mathrm{~min}$ & $240 \mathrm{~min}$ & Baseline & $30 \mathrm{~min}$ & $60 \mathrm{~min}$ & $120 \mathrm{~min}$ & $240 \mathrm{~min}$ & Baseline & $30 \mathrm{~min}$ & $60 \mathrm{~min}$ & $120 \mathrm{~min}$ & $240 \mathrm{~min}$ \\
\hline $\mathrm{VEH}+\mathrm{VEH}$ & 8 & $\begin{array}{l}2.1 \\
(2.0)\end{array}$ & $\begin{array}{l}1.2 \\
(0.7)\end{array}$ & $\begin{array}{l}1.5 \\
(1.2)\end{array}$ & $\begin{array}{l}1.5 \\
(0.8)\end{array}$ & $\begin{array}{l}1.9 \\
(4.6)\end{array}$ & $\begin{array}{l}2.8 \\
(87.0)\end{array}$ & $\begin{array}{l}2.0 \\
(0.9)\end{array}$ & $\begin{array}{l}2.6 \\
(1.4)\end{array}$ & $\begin{array}{l}2.1 \\
(0.7)\end{array}$ & $\begin{array}{l}1.9 \\
(0.5)\end{array}$ & $\begin{array}{l}38.3 \\
(104.0)\end{array}$ & $\begin{array}{l}22.6 \\
(9.7)\end{array}$ & $\begin{array}{l}23.9 \\
(7.7)\end{array}$ & $\begin{array}{l}21.7 \\
(9.8)\end{array}$ & $\begin{array}{l}24.0 \\
(14.4)\end{array}$ \\
\hline VEH+CLZ & 8 & $\begin{array}{l}1.8 \\
(1.7)\end{array}$ & $\begin{array}{l}68.5^{\mathrm{a}} \\
(357 \cdot 3)\end{array}$ & $\begin{array}{l}290.8^{\mathrm{a}} \\
(474.6)\end{array}$ & $\begin{array}{l}21.8^{\mathrm{a}} \\
(477.2)\end{array}$ & $\begin{array}{l}10.2 \\
(43.7)\end{array}$ & $\begin{array}{l}5.9 \\
(10.4)\end{array}$ & $\begin{array}{l}480.0^{a} \\
(357.1)\end{array}$ & $\begin{array}{l}480.0^{a} \\
(0.0)\end{array}$ & $\begin{array}{l}480.0^{\mathrm{a}} \\
(346.9)\end{array}$ & $\begin{array}{l}13.0 \\
(154.8)\end{array}$ & $\begin{array}{l}40.8 \\
(130.8)\end{array}$ & $\begin{array}{l}480.0^{a} \\
(0.0)\end{array}$ & $\begin{array}{l}480.0^{a} \\
(0.0)\end{array}$ & $\begin{array}{l}480.0^{a} \\
(0.0)\end{array}$ & $\begin{array}{l}115.4^{\mathrm{a}} \\
(420.6)\end{array}$ \\
\hline QUI-0.5+CLZ & 8 & $\begin{array}{l}8.7 \\
(16.2)\end{array}$ & $\begin{array}{l}177.2^{\mathrm{a}} \\
(473.2)\end{array}$ & $\begin{array}{l}302.9^{a} \\
(330.3)\end{array}$ & $\begin{array}{l}268.2^{a} \\
(432.7)\end{array}$ & $\begin{array}{l}3.7 \\
(7.6)\end{array}$ & $\begin{array}{l}14.3 \\
(20.6)\end{array}$ & $\begin{array}{l}480.0^{a} \\
(0.0)\end{array}$ & $\begin{array}{l}480.0^{a} \\
(0.0)\end{array}$ & $\begin{array}{l}480.0^{a} \\
(0.0)\end{array}$ & $\begin{array}{l}480.0^{\mathrm{a}, \mathrm{b}} \\
(339.1)\end{array}$ & $\begin{array}{l}65.7 \\
(146.3)\end{array}$ & $\begin{array}{l}480.0^{a} \\
(0.0)\end{array}$ & $\begin{array}{l}480.0^{a} \\
(0.0)\end{array}$ & $\begin{array}{l}480.0^{a} \\
\$(0.0)\end{array}$ & $\begin{array}{l}480.0^{a} \\
(0.0)\end{array}$ \\
\hline QUI-1.o+CLZ & 8 & $\begin{array}{l}5 \cdot 3 \\
(9.1)\end{array}$ & $\begin{array}{l}159.9^{\mathrm{a}} \\
(460.3)\end{array}$ & $\begin{array}{l}129.0^{\mathrm{a}} \\
(240.4)\end{array}$ & $\begin{array}{l}319.3^{\mathrm{a}} \\
(464.0)\end{array}$ & $\begin{array}{l}401.4^{a, b} \\
(442.5)\end{array}$ & $\begin{array}{l}10.4 \\
(75.1)\end{array}$ & $\begin{array}{l}480.0^{a} \\
(0.0)\end{array}$ & $\begin{array}{l}480.0^{a} \\
(0.0)\end{array}$ & $\begin{array}{l}480.0^{a} \\
(0.0)\end{array}$ & $\begin{array}{l}480.0^{a, b} \\
(0.0)\end{array}$ & $\begin{array}{l}143.4 \\
(408.2)\end{array}$ & $\begin{array}{l}480.0^{a} \\
(0.0)\end{array}$ & $\begin{array}{l}480.0^{a} \\
(0.0)\end{array}$ & $\begin{array}{l}480.0^{a} \\
(0.0)\end{array}$ & $\begin{array}{l}480.0^{a} \\
(0.0)\end{array}$ \\
\hline DOI-1.o+CLZ & 8 & $\begin{array}{l}2.2 \\
(1.1)\end{array}$ & $\begin{array}{l}6.9^{b} \\
(38.4)\end{array}$ & $\begin{array}{l}1.8^{\mathrm{b}} \\
(24 \cdot 5)\end{array}$ & $\begin{array}{l}1.7^{b} \\
(1.2)\end{array}$ & $\begin{array}{l}2.2 \\
(5 \cdot 3)\end{array}$ & $\begin{array}{l}7.7 \\
(168.0)\end{array}$ & $\begin{array}{l}8.0^{a} \\
(363.1)\end{array}$ & $\begin{array}{l}2.8^{\mathrm{b}} \\
\left(35^{8.7}\right)\end{array}$ & $\begin{array}{l}3.4 \\
(441.4)\end{array}$ & $\begin{array}{l}3.2 \\
(360.7)\end{array}$ & $\begin{array}{l}107.3 \\
(442.8)\end{array}$ & $\begin{array}{l}391.4^{\mathrm{a}} \\
(440.3)\end{array}$ & $\begin{array}{l}58 \cdot 3^{\mathrm{b}} \\
(453 \cdot 3)\end{array}$ & $\begin{array}{l}214.7^{b} \\
\left(45^{2.0}\right)\end{array}$ & $\begin{array}{l}44.8 \\
(456.8)\end{array}$ \\
\hline DOI-2.5+CLZ & 8 & $\begin{array}{l}1.6 \\
(2.6)\end{array}$ & $\begin{array}{l}1.8^{b} \\
(0.4)\end{array}$ & $\begin{array}{l}1.3^{b} \\
(7.2)\end{array}$ & $\begin{array}{l}1.3^{\mathrm{b}} \\
(34.6)\end{array}$ & $\begin{array}{l}1.8 \\
(4.9)\end{array}$ & $\begin{array}{l}2.7 \\
(1.7)\end{array}$ & $\begin{array}{l}21.8^{a} \\
(371.5)\end{array}$ & $\begin{array}{l}2.5^{b} \\
(63.4)\end{array}$ & $\begin{array}{l}2.4^{b} \\
(34.8)\end{array}$ & $\begin{array}{l}2.2 \\
(3.8)\end{array}$ & $\begin{array}{l}37.13 \\
(32.0)\end{array}$ & $\begin{array}{l}480.0^{a} \\
(396.9)\end{array}$ & $\begin{array}{l}56.93^{b} \\
(372.2)\end{array}$ & $\begin{array}{l}45.13^{b} \\
(104.7)\end{array}$ & $\begin{array}{l}34 \cdot 4^{b} \\
(54 \cdot 7)\end{array}$ \\
\hline
\end{tabular}

Data are represented as median \pm interquartile range.

a. $p<0.05$ relative to the $\mathrm{VEH}+\mathrm{VEH}$ group; b. $p<0.05$ relative to the $\mathrm{VEH}+\mathrm{CLZ}$ group. 


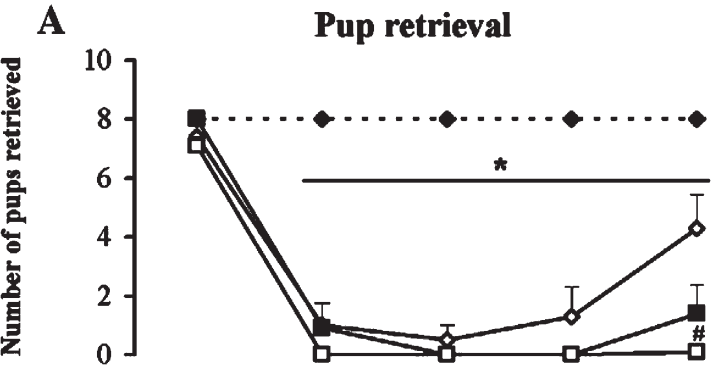

B
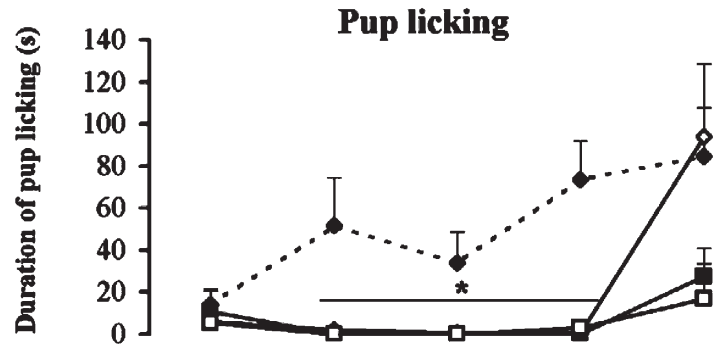

C

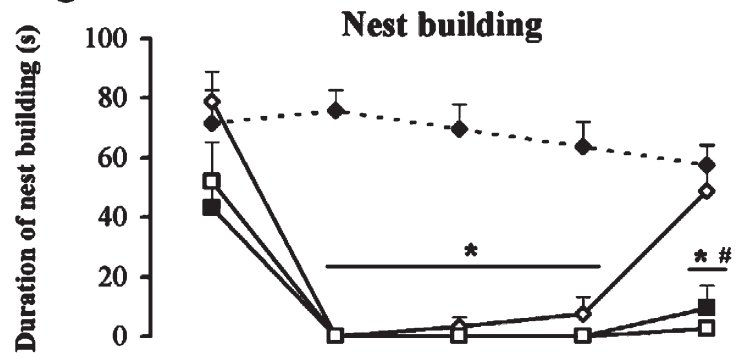

D

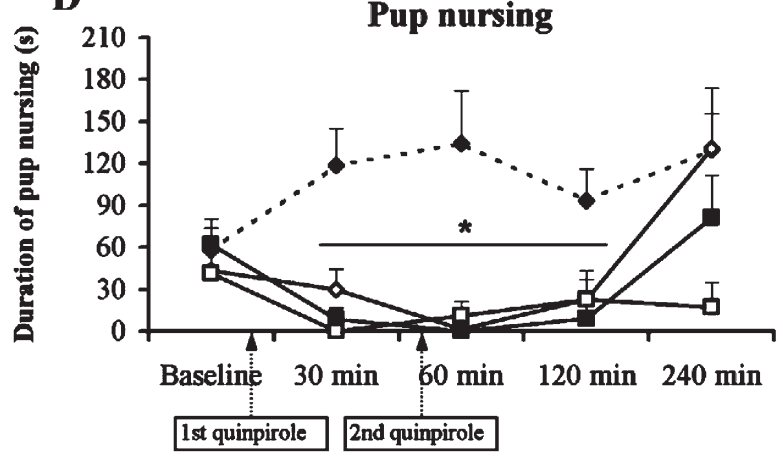

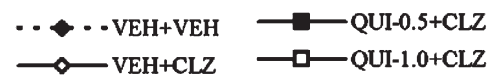

Figure 3. The time course of effects of the dopamine $\mathrm{D}_{2} / \mathrm{D}_{3}$ receptor agonist quinpirole on various CLZ-induced maternal behavior deficits in postpartum female rats. Pup retrieval (A), pup licking (B), nest building (C) and pup nursing (D) were tested at baseline, 30, 60, 120 and 240 min after injection of CLZ or vehicle. CLZ disrupted all maternal behaviors tested $(\mathrm{A}-\mathrm{D})$. Both doses of quinpirole $(0.5$ and $1.0 \mathrm{mg} / \mathrm{kg}$ ) failed to improve the maternal behavior deficits induced by CLZ (A-D), but rather worsened pup retrieval (A) and nest building (C) deficits. Data were represented as mean + SEM. * $p<0.05$ versus VEH+VEH control; ${ }^{\#} p<0.05$ versus $\mathrm{VEH}+\mathrm{CLZ}$ group.

the normal level at the 60 min test point $(p=0.035)$ at a dose of $1.0 \mathrm{mg} / \mathrm{kg}$ as well as at the 60 and 120 min test points (both ps < o.o1) at a dose of $2.5 \mathrm{mg} / \mathrm{kg}$. For the last pup retrieval latency, both doses of DOI completely rescued the disruption at the 60 and $120 \mathrm{~min}(0.001<$ all ps < o.o1) test points. Furthermore, $2.5 \mathrm{mg} / \mathrm{kg}$ of DOI shortened the last pup retrieval latency at the $240 \mathrm{~min}$ test point $(p=0.001)$.

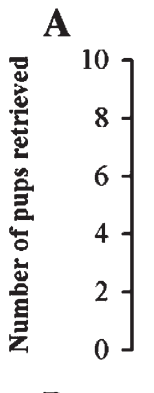

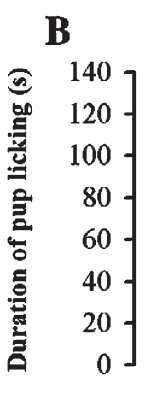

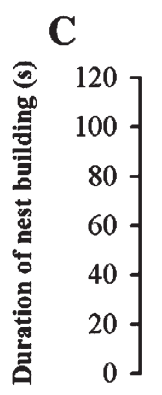

D

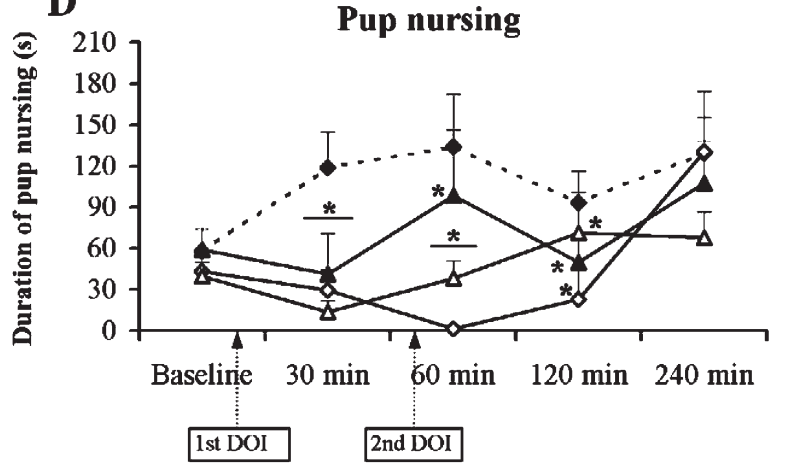

$\underset{\cdots-\text { VEII }+ \text { VEII } \longrightarrow \text { DOI-1.0+CLZ }}{\longrightarrow \text { DOI- } 2.5+\mathrm{CLZ}}$

Figure 4. The time course of effects of the $5-\mathrm{HT}_{2 \mathrm{~A} / 2 \mathrm{C}}$ receptor agonist DOI on various CLZ-induced maternal behavior deficits in postpartum female rats. Pup retrieval (A), pup licking (B), nest building (C) and pup nursing (D) were tested at baseline, 30, 6o, 120 and $240 \mathrm{~min}$ after injection of CLZ or vehicle. CLZ disrupted all maternal behaviors tested (AD). Both doses of DOI (1.o and $2.5 \mathrm{mg} / \mathrm{kg}$ ) significantly improved the pup retrieval and pup licking deficits induced by CLZ (A, B). However, DOI did not improve the CLZ-induced disruption on nest building and pup nursing (C, D). Data were represented as mean + SEM. * $p<0.05$ versus VEH+VEH control; ${ }^{\#} p<0.05$ versus $\mathrm{VEH}+\mathrm{CLZ}$ group.

3.2.3.2. Number of pups retrieved. Both doses of DOI increased the number of pups retrieved in the CLZ-treated rats. One-way ANOVA and post hoc tests showed that there was a significant difference between the DOI-1.o+CLZ group and the $\mathrm{VEH}+\mathrm{CLZ}$ group at the 60 and 120 min test points $(p=0.006$ for $60 \mathrm{~min}, p=0.008$ for $120 \mathrm{~min}$ ), whereas the DOI-2.5+CLZ group differed significantly from the $\mathrm{VEH}+\mathrm{CLZ}$ group even at 
the 240 min test point (Figure $4 \mathrm{~A}$, o.001 $<$ all $p s<0.05$ ). Further analysis showed that the reversing effect of $1.0 \mathrm{mg} / \mathrm{kg}$ of DOI reached the normal level at the 60 and 120 min test points while the $2.5 \mathrm{mg} / \mathrm{kg}$ of DOI restored the CLZ-induced disruption to the normal level at 6o, 120 and 240 min test points (Figure $4 \mathrm{~A}$, all $p s>0.05)$. It appears that the strongest reversal effect of DOI occurred 120 min after CLZ administration (Figure 4A).

3.2.3.3. Pup licking. Both doses of DOI alleviated the CLZ-induced disruption on pup licking. One-way ANOVA and post hoc tests showed that there was a significant difference between the DOI-1.0+CLZ group and the VEH+CLZ group at the 120 min test point $(p=0.049)$, while the DOI-2.5+CLZ group differed significantly from the VEH+CLZ group at the 60 and 120 min test points (Figure $4 \mathrm{~B}, p=0.034$ for $60 \mathrm{~min}, p=0.015$ for $60 \mathrm{~min}$ ). Further analysis showed that only $2.5 \mathrm{mg} / \mathrm{kg}$ of DOI restored this behavior to the normal level at the 60 and 120 min test points when the two DOI+CLZ groups were compared with the $\mathrm{VEH}+\mathrm{VEH}$ control group (Figure $4 \mathrm{~B}$, both $p s>0.05$ ).

3.2.3.4. Nest building and pup nursing. Compared to the reversing effects on pup retrieval and pup licking, DOI at the currently tested doses appeared to be ineffective in reversing the CLZ-induced deficits on nest building and pup nursing. Post hoc tests on nest building and pup nursing revealed that there was no significant difference between the two DOI+CLZ groups and the VEH+CLZ group (Figure $4 \mathrm{C}, \mathrm{D}$, all $\mathrm{ps}>0.05$ ).

\section{Discussion}

The present study demonstrates an interesting double dissociation between dopamine and serotonin receptor mechanisms in the mediation of HAL- and CLZ-induced maternal behavior deficits in postpartum rats. Acute treatment of HAL and CLZ disrupted various components of rat maternal behavior. Pretreatment of QUI, a selective $\mathrm{D}_{2} / \mathrm{D}_{3}$ dopaminergic receptor agonist, but not DOI, a selective ${ }_{5}-\mathrm{HT}_{2 \mathrm{~A} / 2 \mathrm{C}}$ serotonergic receptor agonist, dose-dependently improved HAL-induced disruption of pup approach, pup retrieval, pup licking and nest building, whereas pretreatment of DOI, but not QUI, dose-dependently improved CLZ-induced disruption of pup approach, pup retrieval and pup licking. These data strongly suggest that the HAL-induced maternal deficits are primarily mediated by its blockade of $\mathrm{D}_{2}$ dopamine receptors, whereas the CLZ-induced maternal deficits are primarily mediated by the blockade of $5-\mathrm{HT}_{2 \mathrm{~A} / 2 \mathrm{C}}$ receptors.

The dopamine systems have been well documented to play an important role in the regulation of maternal behavior. For example, systemic (e.g., haloperidol, a $\mathrm{D}_{2}$ antagonist) or microinfusion of dopamine receptor antagonists such as $\mathrm{SCH}-23390$ (a $\mathrm{D}_{1}$ antagonist), pimozide (a $\mathrm{D}_{2}$ antagonist) and cis-flupenthixol (a mixed $\mathrm{D}_{1} / \mathrm{D}_{2}$ antagonist) into the specific brain regions implicated in maternal behavior (e.g., medial preoptic area, nucleus accumbens) disrupts various active maternal behaviors (Byrnes et al., 2002; Giordano et al., 1990; Keer and Stern, 1999; Li et al., 2004; Miller and Lonstein, 2005; Numan et al., 2005; Numan and Stolzenberg, 2009; Silva et al., 2001, 2003; Stern and Taylor, 1991). 6 -OHDA lesion of the ventral striatum and ventral tegmental area disrupts pup retrieval (Hansen, 1994; Hansen et al., 1991a, 1991b). Additionally, mother-pup separation, which putatively enhances maternal motivation (Hansen, 1994), stimulates dopamine release in the ventral striatum of maternal rats (Hansen et al., 1993). Because HAL is primarily a $D_{2}$ receptor antagonist, we hypothesized that it disrupts maternal behavior by blocking $\mathrm{D}_{2}$ dopamine receptors. We tested this hypothesis by co-administrating QUI, a selective $\mathrm{D}_{2} / \mathrm{D}_{3}$ agonist together with $\mathrm{HAL}$ and examined whether QUI could reverse the effects of HAL. As expected, QUI did significantly improve the HAL-induced maternal behavior deficits. HAL rats pretreated with QUI showed shortened pup approach and retrieval latency than those pre- treated with vehicle. This result is in general agreement with a previous study showing that apomorphine, a mixed $D_{1} / D_{2}$ receptor agonist with a preferential affinity and potency for the $\mathrm{D}_{2}$ over $D_{1}$ receptor subtype (Kebabian and Calne, 1979), reversed HAL-induced pup retrieval deficits in postpartum rats (Giordano et al., 1990). We extended this line of research by showing that HAL specifically acts on $\mathrm{D}_{2}$ receptors to achieve its disruptive effect. Of note, this finding does not necessarily rule out the involvement of the $\mathrm{D}_{1}$ receptor mechanism because HAL does have a weak $D_{1}$ antagonism (Miyamoto et al., 2005), and other studies also find that $\mathrm{D}_{1}$ receptors are involved in the regulation of maternal behavior (Miller and Lonstein, 2005; Numan et al., 2005; Numan and Stolzenberg, 2009).

The lack of the effect of DOI treatment on HAL-induced maternal behavior deficits is not surprising given the fact that DOI is a selective $5-\mathrm{HT}_{2 \mathrm{~A} / 2 \mathrm{C}}$ agonist and HAL lacks an action on these serotonergic receptor systems. Interestingly, DOI pretreatment further decreased the duration of pup nursing in the HAL-treated rats (see Figure 2D). Informal observations indicate that after the pups were returned to the cage, the HAL rats pretreated with $2.5 \mathrm{mg} / \mathrm{kg}$ of DOI did not approach and retrieve their pups, but stayed in the corner of the cage with no apparent movement. This may explain the reduction of pup nursing by DOI. In light that DOI itself reduces locomotor activity (Hameleers et al., 2007; Krebs-Thomson and Geyer, 1996; Mittman and Geyer, 1991; Wing et al., 1990), it is possible that DOIinduced hypolocomotor activity may have contributed to its disruptive effect on pup nursing.

Our original hypothesis that QUI may also attenuate the CLZ-induced disruption to some extent, as CLZ also possesses a $\mathrm{D}_{2}$ antagonism, was not supported by the present findings. In contrast, QUI actually worsened some maternal behavior deficits, such as on pup retrieval and nest building. These findings indicate that CLZ-induced maternal deficits are not primarily mediated by its weak antagonism of $\mathrm{D}$ receptor. Our preliminary work (data not shown) finds that QUUI at a dose of $1.0 \mathrm{mg}$ / $\mathrm{kg}$ by itself disrupts pup retrieval and nest building. Therefore, it is possible that a combination of clozapine and QUI may provide an additive disruption on the CLZ-induced maternal deficits.

The most striking finding from the present study was that DOI pretreatment rescued most, if not all, maternal behavior deficits induced by CLZ. We found that CLZ rats pretreated with DOI took a much shorter time to initiate contact with pups and retrieve their pups into the nest sites (Table 2), retrieved more pups (Figure 4A) and spent more time licking their pups than CLZ rats pretreated with vehicle (Figure $4 \mathrm{~B}$ ). CLZ has a unique and multifaceted pharmacological, behavioral and clinical profile in comparison with other antipsychotic drugs (Matsubara et al., 1993; Meltzer, 1989; Safferman et al., 1991; Schmauss et al., 1989) due to its multiple-receptor action, including a relatively high affinity for $\mathrm{D}_{4}$, histaminergic $\left(\mathrm{H}_{1}\right)$, muscarinic, serotoninergic (5- $\left.\mathrm{HT}_{2}\right)$ and alpha-1-adrenergic receptors (Baldessarini et al., 1992; Lane et al., 1988; Meltzer, 1989; Meltzer et al., 1989a; Miller and Hiley, 1974; Seeman, 1992; Zavitsanou et al., 2007), moderate affinity for $\mathrm{D}_{1}, \mathrm{D}_{2}, \mathrm{D}_{5}$, alpha-2-adrenergic and 5-HT $\mathrm{H}_{3}$ receptors (Ellenbroek et al., 1991; Matsubara et al., 1993; Miyamoto et al., 2005; Murray and Waddington, 1990; Perry et al., 1983; Remington and Kapur, 200o). The unique antipsychotic property of CLZ (e.g., low EPS and less prolactin elevation) has been correlated with its low affinity and fast dissociation at the $\mathrm{D}_{2}$ receptor (Kapur and Remington, 2001; Kapur and Seeman, 2001; Seeman, 2002). This profile makes it difficult to pinpoint the exact mechanisms mediating the antipsychotic and behavioral effects of CLZ. Our finding that DOI dose-dependently improved the CLZ-induced maternal behavior deficits suggests that CLZ exerts its disruptive effect on maternal behavior through a $5-\mathrm{HT}_{2 \mathrm{~A} / 2 \mathrm{C}}$ receptor-mediated mechanism, and that this effect thus might not be directly related to its antipsychotic efficacy, which is mediated by blockade of $\mathrm{D}_{2}$ receptors (Seeman, 2002). 
There are several possible mechanisms underlying the reversing effect of DOI on CLZ-induced maternal behavior deficits. First, DOI may directly activate the $5-\mathrm{HT}_{2 \mathrm{~A} / 2 \mathrm{C}}$ receptors localized in the brain regions important for maternal behavior, such as the nucleus accumbens (NA) and the ventral tegmental area (VTA), etc. There is considerable evidence demonstrating that moderate to high levels of $5-\mathrm{HT}_{2 \mathrm{~A} / 2 \mathrm{C}}$ receptor immunoreactivity (Bubar et al., 2005; Clemett et al., 2000; Cornea-Hébert et al., 1999; Jakab and Goldman-Rakic, 1998) and mRNAs (EberleWang et al., 1997; Pompeiano et al., 1994; Wright et al., 1995) are expressed in the NA and VTA, thus, DOI may antagonize CLZ's blockade on $5-\mathrm{HT}_{2 \mathrm{~A} / 2 \mathrm{C}}$ receptors through competitive binding to 5 -HT receptors in these areas to alleviate the CLZ-induced maternal behavior deficits.

Second, DOI may improve CLZ-induced maternal deficits through its indirect action on the dopaminergic systems. The mesolimbic dopamine system, originating in the VTA and terminating in the NA has been implicated in the appetitive aspects of maternal behavior (Hansen, 1994; Hansen et al., 1991a, 1991b; Hansen et al., 1993; Numan, 2007; Numan et al., 2005). Recently, 5- $\mathrm{HT}_{2 \mathrm{~A} / 2 \mathrm{C}}$ receptors were found to be localized on the dopamine neurons in the VTA (Bubar and Cunningham, 2007; Doherty and Pickel, 2000; Ji et al., 2006; Nocjar et al., 2002). This finding provides evidence in support of the possible interaction between the serotonin and dopamine systems in the VTA (Alex and Pehek, 2007; Di Matteo et al., 2001). More importantly, a growing body of evidence shows that $5-\mathrm{HT}_{2}$ receptors play a prominent role in the modulation of mesolimbic dopamine-mediated function. For example, in the NA, activation of $5-\mathrm{HT}_{2}$ receptor appears to facilitate dopamine release that can be blocked by local injection of a $5-\mathrm{HT}_{2}$ receptor antagonist (Parsons and Justice, 1993). DOI, a mixed ${ }_{5}^{2} \mathrm{HT}_{2 \mathrm{~A} / 2 \mathrm{C}}$ agonist, has been shown to increase extracellular levels of dopamine in the posterior NA (Bowers et al., 200o). Thus, it is possible that DOI may reverse the effect of CLZ by regulating the DA release in the NA and thus indirectly regulate maternal behavior via the DA system. Future research should directly address the neural pathways that mediate the modulatory effects of $5-\mathrm{HT}_{2 \mathrm{~A} / 2 \mathrm{C}}$ receptors on the mesolimbic dopamine systems.

Third, at the behavioral level, the diminished sedation could be a contributing factor in reversing CLZ-induced maternal deficits by DOI. In the present study, we noted that DOI treatment significantly alleviated CLZ-induced sedative effect as those rats showed increased motor activity, no sign of closed eyes or bowed head. It has been reported that acute and repeated injection of CLZ at a dose of $10.0 \mathrm{mg} / \mathrm{kg}$ produces substantial sedation in animals (Chesler and Salamone, 1996). The CLZ-induced sedative effect has also been reported in the clinic (Burke and Sebastian, 1993; Safferman et al., 1991). Moreover, recent work from our laboratory shows that the sedative effect of CLZ contributes to its disruption on maternal behavior (Zhao and Li, 2009). At this point, it is still premature to suggest that DOI reverses CLZ's disruption on maternal behavior by alleviating the sedative effect of CLZ, because CLZ is not known to cause sedation by blocking $5-\mathrm{HT}_{2 \mathrm{~A} / 2 \mathrm{C}}$ receptors, but rather by blocking alpha-adrenergic and histamine receptors (Lieberman et al., 1989; Safferman et al., 1991). More research is needed to examine whether CLZ can cause sedation via action on $5-\mathrm{HT}_{22 / 2 \mathrm{C}}$ receptors.

Because improvement of CLZ-induced disruption of nest rebuilding was not apparently observed after DOI pretreatment, it is possible that other neurotransmitter systems may be involved in CLZ-induced nest building deficit. One such system could involve the dopamine $\mathrm{D}_{2} / \mathrm{D}_{3}$ receptors, as our results show that HAL-induced disruption of nest building was reversed and restored to the normal level by QUI, a selective $\mathrm{D}_{2} / \mathrm{D}_{3}$ receptor agonist. Other systems may include dopamine $\mathrm{D}_{1}, \mathrm{D}_{4}$ and $\mathrm{D}_{5}$ receptors. CLZ has high affinity for $\mathrm{D}_{4}$ and moderate affinity for
$\mathrm{D}_{1}$ and $\mathrm{D}_{5}$ receptors. Consistent with this hypothesis, previous studies have shown that $D_{1}$ receptor activity is critical for the regulation of maternal behavior. Microinjection of a dopamine $\mathrm{D}_{1}$ receptor antagonist $\mathrm{SCH}-23390$ into the medial preoptic area (MPOA) or nucleus accumbens (NA) greatly impairs pup retrieval in postpartum rats (Miller and Lonstein, 2005; Numan et al., 2005). Microinfusion of a dopamine $D_{1}$ receptor agonist SKF38393 into either the MPOA or the NA promotes the onset of maternal behavior in pregnancy-terminated rats (Stolzenberg et al., 2007). However, it is unknown whether the $\mathrm{D}_{4}$ and/or $\mathrm{D}_{5}$ receptors are involved in the regulation of maternal behavior due to lack of evidence. Alternatively, nest building activity may still be mediated by $5-\mathrm{HT}_{2 \mathrm{~A} / 2 \mathrm{C}}$ receptors, but is more sensitive and vulnerable to pharmacological intervention ( $\mathrm{Li}$ et al., 2004; Silva et al., 2001; Zhao and Li, 2009). Future work should address this issue in detail.

The present study provides strong evidence supporting the involvement of $5-\mathrm{HT}_{2 \mathrm{~A} / 2 \mathrm{C}}$ receptors in the mediation of rat maternal behavior. Previous work on this issue is inadequate and inconsistent. For example, Brunner et al. (1999) reported that 5 - $\mathrm{HT}_{1 \mathrm{~B}}$ receptor knockout mother mice did not display pup retrieval deficits. More recently, Lerch-Haner et al. (2008) reported that transgenic mouse dams with a specific disruption in serotonin neuron development displayed profound maternal deficits (e.g., pup retrieval, pup nursing, nest building). This study, however, did not answer which subtypes of 5 -HT receptor are implicated in maternal activity. Other studies have found that $5-\mathrm{HT}_{1 \mathrm{~B}}$ and $5-\mathrm{HT}_{2 \mathrm{~A} / 2 \mathrm{C}}$ receptors are involved in maternal aggressive behavior (De Almeida et al., 2005, 2006a, 2006b; Olivier et al., 1995; Veiga et al., 2007). For example, intracerebroventricular injections of DOI, a $5-\mathrm{HT}_{2 \mathrm{~A} / 2 \mathrm{C}}$ agonist, inhibited maternal aggression in postpartum female rats (De Almeida and Lucion, 1994). To the best of our knowledge, the present study was the first to demonstrate that $5-\mathrm{HT}_{2 \mathrm{~A} / 2 \mathrm{C}}$ receptors may be important in regulating rat maternal behavior.

Consistent with our previous work (Li et al., 2004), we found that HAL and CLZ had different time courses of action. HAL tended to produce a prolonged disruption, whereas CLZ produced a transient one. For instance, the HAL-induced disruption of nest building was still apparent even at the $240 \mathrm{~min}$ test point ( $4 \mathrm{~h}$ post-injection), whereas the effect of CLZ was diminished (Figure 1 \& Figure 3, C). It appears that the reversal effect of QUI on HAL-induced maternal deficits also differed in regard to time course of action from that of DOI on CLZ-induced deficits. For example, the reversal effect of DOI on CLZinduced disruption of pup retrieval was somewhat delayed in onset when compared to that of quinpirole on HAL-induced impairment (Figure 1 \& Figure $4 \mathrm{~A}$ ), which may be attributable to the rapid peak plasma concentration of quinpirole (Whitaker and Lindstrom, 1987).

Taken together, the present study demonstrates an interesting double dissociation receptor mechanism underlying the HAL and CLZ-induced maternal behavior deficits. Our data suggest that the HAL-induced maternal deficits are primarily mediated by the blockade of $\mathrm{D}_{2}$ dopamine receptors, whereas the CLZ-induced maternal deficits are primarily mediated by the blockade of ${ }_{5}-\mathrm{HT}_{2 \mathrm{~A} / 2 \mathrm{C}}$ receptors. Because not all components of CLZ-induced maternal behavior deficits were reversed by DOI, other receptor mechanisms such as the $\mathrm{D}_{1}$ receptor may also be involved, prompting the need for further investigation.

Acknowledgements - This research was supported by a grant from the National Institute of Mental Health (5Ro3MHo8o822-02). The content is solely the responsibility of the authors and does not necessarily represent the official views of the National Institute of Mental Health or the National Institutes of Health. We would like to thank Wei He for his administrative and technical help with this work. 


\section{References}

Alex KD, Pehek EA. Pharmacologic mechanisms of serotonergic regulation of dopamine neurotransmission. Pharmacol Ther 2007;113:296-320.

Baldessarini RJ, Huston-Lyons D, Campbell A, Marsh E, Cohen BM. Do central antiadrenergic actions contribute to the atypical properties of clozapine? Br J Psychiatr Suppl 1992;17:12-6.

Bowers BJ, Henry MB, Thielen RJ, McBride WJ. Serotonin 5-HT(2) receptor stimulation of dopamine release in the posterior but not anterior nucleus accumbens of the rat. J Neurochem 2000;75:1625-33.

Brunner D, Buhot MC, Hen R, Hofer M. Anxiety, motor activation, and maternal-infant interactions in $5 \mathrm{HT} 1 \mathrm{~B}$ knockout mice. Behav Neurosci 1999;113:587-601.

Bubar MJ, Cunningham KA. Distribution of serotonin $5-\mathrm{HT}_{2} \mathrm{C}$ receptors in the ventral tegmental area. Neuroscience 2007;146:286-97.

Bubar MJ, Seitz PK, Thomas ML, Cunningham KA. Validation of a selective serotonin 5 - $\mathrm{HT}(2 \mathrm{C})$ receptor antibody for utilization in fluorescence immunohistochemistry studies. Brain Res 2005;1063:105-13.

Burke M, Sebastian CS. Treatment of clozapine sedation. Am J Psychiatry 1993;150: 1900-1.

Byrnes EM, Rigero BA, Bridges RS. Dopamine antagonists during parturition disrupt maternal care and the retention of maternal behavior in rats. Pharmacol Biochem Behav 2002;73:869-75.

Chesler EJ, Salamone JD. Effects of acute and repeated clozapine injections on cholinomimetic-induced vacuous jaw movements. Pharmacol Biochem Behav 1996;54:619-24.

Clemett DA, Punhani T, Duxon MS, Blackburn TP, Fone KC. Immunohistochemical localisation of the $5-\mathrm{HT}_{2} \mathrm{C}$ receptor protein in the rat CNS. Neuropharmacology 2000;39:123-32.

Cornea-Hébert V, Riad M, Wu C, Singh SK, Descarries L. Cellular and subcellular distribution of the serotonin 5 - $\mathrm{HT}_{2} \mathrm{~A}$ receptor in the central nervous system of adult rat. J Comp Neurol 1999;409:187-209.

De Almeida RM, Lucion AB. Effects of intracerebroventricular administration of 5 -HT receptor agonists on the maternal aggression of rats. Eur J Pharmacol 1994;264: 445-8.

De Almeida RM, Giovenardi M, da Silva SP, de Oliveira VP, Stein DJ. Maternal aggression in Wistar rats: effect of $5-\mathrm{HT}_{2} \mathrm{~A} / 2 \mathrm{C}$ receptor agonist and antagonist microinjected into the dorsal periaqueductal gray matter and medial septum. Braz J Med Biol Res 2005;38:597-602.

De Almeida RM, Giovenardi M, da Silva SP, de Oliveira VP, Stein DJ. The effect of 5 -HT $(2 \mathrm{a} / 2 \mathrm{c})$ receptor agonist microinjected into central amygdaloid nucleus and median preoptic area on maternal aggressive behavior in rats. Rev Bras Psiquiatr 2006a;28:130-4

De Almeida RM, Rosa MM, Santos DM, Saft DM, Benini Q, Miczek KA. 5 -HT( $\left.{ }_{1} \mathrm{~B}\right)$ receptors, ventral orbitofrontal cortex, and aggressive behavior in mice. Psychopharmacology (Berl) 20o6b;185:441-50.

Deutch AY, Duman RS. The effects of antipsychotic drugs on Fos protein expression in the prefrontal cortex: cellular localization and pharmacological characterization. Neuroscience 1996;70:377-89.

Di Matteo V, De Blasi A, Di Giulio C, Esposito E. Role of 5-HT(2C) receptors in the control of central dopamine function. Trends Pharmacol Sci 2001;22:229-32.

Doherty MD, Pickel VM. Ultrastructural localization of the serotonin $2 \mathrm{~A}$ receptor in dopaminergic neurons in the ventral tegmental area. Brain Res 2000;864:176-85.

Dollinger MJ, Holloway WR, Denenberg VH. Parturition in the rat (Rattus norvegicus): normative aspects and the temporal patterning of behaviours. Behav Processes 1980;5:21-37.

Dragunow M, Robertson GS, Faull RL, Robertson HA, Jansen K. D2 dopamine receptor antagonists induce fos and related proteins in rat striatal neurons. Neuroscience 1990;37:287-94.

Eberle-Wang K, Mikeladze Z, Uryu K, Chesselet MF. Pattern of expression of the serotonin $2 \mathrm{C}$ receptor messenger RNA in the basal ganglia of adult rats. J Comp Neurol 1997;384:233-47.

Ellenbroek BA, Artz MT, Cools AR. The involvement of dopamine D1 and D2 receptors in the effects of the classical neuroleptic haloperidol and the atypical neuroleptic clozapine. Eur J Pharmacol 1991;196:103-8.
Fleming AS, Corter C. Factors influencing maternal responsiveness in humans: usefulness of an animal model. Psychoneuroendocrinology 1988;13:189-212.

Galef Jr BG. Development of olfactory control of feeding-site selection in rat pups. J Comp Physiol Psychol 1981;95:615-22.

Giordano AL, Johnson AE, Rosenblatt JS. Haloperidol-induced disruption of retrieval behavior and reversal with apomorphine in lactating rats. Physiol Behav 1990;48: 211-4.

Hameleers R, Blokland A, Steinbusch HW, Visser-Vandewalle V, Temel Y. Hypomobility after DOI administration can be reversed by subthalamic nucleus deep brain stimulation. Behav Brain Res 2007;185:65-7.

Hansen S. Maternal behavior of female rats with 6-OHDA lesions in the ventral striatum: characterization of the pup retrieval deficit. Physiol Behav 1994;55:615-20.

Hansen S, Harthon C, Wallin E, Löfberg L, Svensson K. Mesotelencephalic dopamine system and reproductive behavior in the female rat: effects of ventral tegmental 6- hydroxydopamine lesions on maternal and sexual responsiveness. Behav Neurosci 1991a;105:588-98.

Hansen S, Harthon C, Wallin E, Löfberg L, Svensson K. The effects of 6-OHDA-induced dopamine depletions in the ventral or dorsal striatum on maternal and sexual behavior in the female rat. Pharmacol Biochem Behav 1991b;39:71-7.

Hansen S, Bergvall AH, Nyiredi S. Interaction with pups enhances dopamine release in the ventral striatum of maternal rats: a microdialysis study. Pharmacol Biochem Behav 1993;45:673-6.

Ichikawa J, Meltzer HY. DOI, a 5- $\mathrm{HT}_{2} \mathrm{~A} / 2 \mathrm{C}$ receptor agonist, potentiates amphetamineinduced dopamine release in rat striatum. Brain Res 1995;698:204-8.

Ichikawa J, Dai J, Meltzer HY. DOI, a $5-\mathrm{HT}_{2} \mathrm{~A} / 2 \mathrm{C}$ receptor agonist, attenuates clozapineinduced cortical dopamine release. Brain Res 2001;907:151-5.

Jakab RL, Goldman-Rakic PS. 5-Hydroxytryptamine2A serotonin receptors in the primate cerebral cortex: possible site of action of hallucinogenic and antipsychotic drugs in pyramidal cell apical dendrites. Proc Natl Acad Sci USA 1998;95: 735-40.

Ji SP, Zhang Y, Van Cleemput J, Jiang W, Liao M, Li L, et al. Disruption of PTEN coupling with 5 - $\mathrm{HT}_{2} \mathrm{C}$ receptors suppresses behavioral responses induced by drugs of abuse. Nat Med 2006;12:324-9.

Kapur S, Remington G. Atypical antipsychotics: new directions and new challenges in the treatment of schizophrenia. Annu Rev Med 2001;52:503-17.

Kapur S, Seeman P. Does fast dissociation from the dopamine d(2) receptor explain the action of atypical antipsychotics: a new hypothesis. Am J Psychiatry 2001;158: 360-9.

Kebabian JW, Calne DB. Multiple receptors for dopamine. Nature 1979;277:93-6.

Keer SE, Stern JM. Dopamine receptor blockade in the nucleus accumbens inhibits maternal retrieval and licking, but enhances nursing behavior in lactating rats. Physiol Behav 1999;67:659-69.

Krebs-Thomson K, Geyer MA. The role of 5-HT(1A) receptors in the locomotorsuppressant effects of LSD:WAY-100635 studies of 8-OHDPAT, DOI and LSD in rats. Behav Pharmacol 1996;7:551-9.

Kuroki T, Meltzer HY, Ichikawa J. 5-HT 2A receptor stimulation by DOI, a $5-\mathrm{HT} 2 \mathrm{~A} / 2 \mathrm{C}$ receptor agonist, potentiates amphetamine-induced dopamine release in rat medial prefrontal cortex and nucleus accumbens. Brain Res 2003;972:216-21.

Lane RF, Blaha CD, Rivet JM. Selective inhibition of mesolimbic dopamine release following chronic administration of clozapine: involvement of alpha 1-noradrenergic receptors demonstrated by in vivo voltammetry. Brain Res 1988;460:398-401.

Lerch-Haner JK, Frierson D, Crawford LK, Beck SG, Deneris ES. Serotonergic transcriptional programming determines maternal behavior and offspring survival. Nat Neurosci 2008;11:1001-3.

Li M, Davidson P, Budin R, Kapur S, Fleming AS. Effects of typical and atypical antipsychotic drugs on maternal behavior in postpartum female rats. Schizophr Res 2004;70:69-8o.

Li M, Budin R, Fleming AS, Kapur S. Effects of novel antipsychotics, amisulpiride and aripiprazole, on maternal behavior in rats. Psychopharmacology (Berl) 2005a;181: 600-10. 
Li M, Budin R, Fleming AS, Kapur S. Effects of chronic typical and atypical antipsychotic drug treatment on maternal behavior in rats. Schizophr Res 2005b;75:325-36.

Lieberman JA, Kane JM, Johns CA. Clozapine: guidelines for clinical management. J Clin Psychiatry 1989;50:329-38.

Matsubara S, Matsubara R, Kusumi I, Koyama T, Yamashita I. Dopamine D1, D2 and serotoninz receptor occupation by typical and atypical antipsychotic drugs in vivo. J Pharmacol Exp Ther 1993;265:498-508.

Meltzer HY. Clinical studies on the mechanism of action of clozapine: the dopamine-serotonin hypothesis of schizophrenia. Psychopharmacology (Berl) 1989;99(Suppl): S18-27.

Meltzer HY, Matsubara S, Lee JC. The ratios of serotonin2 and dopaminez affinities differentiate atypical and typical antipsychotic drugs. PsychopharmacolBull 1989a;25: 390-2.

Meltzer HY, Matsubara S, Lee JC. Classification of typical and atypical antipsychotic drugs on the basis of dopamine D-1, D-2 and serotonin2 pKi values. J Pharmacol Exp Ther 1989b;251:238-46.

Meltzer HY, Li Z, Kaneda Y, Ichikawa J. Serotonin receptors: their key role in drugs to treat schizophrenia. Prog Neuro-psychopharmacol Biol Psychiatry 2003;27:1159-72.

Miller RJ, Hiley CR. Anti-muscarinic properties of neuroleptics and drug-induced Parkinsonism. Nature 1974;248:596-7.

Miller SM, Lonstein JS. Dopamine d 1 and d2 receptor antagonism in the preoptic area produces different effects on maternal behavior in lactating rats. Behav Neurosci 2005;119:1072-83.

Mittman SM, Geyer MA. Dissociation of multiple effects of acute LSD on exploratory behavior in rats by ritanserin and propranolol. Psychopharmacology (Berl) 1991;105: 69-76.

Miyamoto S, Duncan GE, Marx CE, Lieberman JA. Treatments for schizophrenia: a critical review of pharmacology and mechanisms of action of antipsychotic drugs. Mol Psychiatry 2005;10:79-104.

Murray AM, Waddington JL. The interaction of clozapine with dopamine D1 versus dopamine D2 receptor-mediated function: behavioural indices. Eur J Pharmacol 1990;186:79-86.

Nocjar C, Roth BL, Pehek EA. Localization of 5-HT(2A) receptors on dopamine cells in subnuclei of the midbrain Aro cell group. Neuroscience 2002;111:163-76.

Numan M. Motivational systems and the neural circuitry of maternal behavior in the rat. Dev Psychobiol 2007;49:12-21.

Numan M, Insel TR. The neurobiology of parental behavior. New York: Springer; 2003. p. 236-7.

Numan M, Stolzenberg DS. Medial preoptic area interactions with dopamine neural systems in the control of the onset and maintenance of maternal behavior in rats. Front Neuroendocrinol 2009;30:46-64.

Numan M, Numan MJ, Pliakou N, Stolzenberg DS, Mullins OJ, Murphy JM, et al. The effects of D1 or D2 dopamine receptor antagonism in the medial preoptic area, ventral pallidum, or nucleus accumbens on the maternal retrieval response and other aspects of maternal behavior in rats. Behav Neurosci 2005;119:1588-604.

Olivier B, Mos J, van Oorschot R, Hen R. Serotonin receptors and animal models of aggressive behavior. Pharmacopsychiatry 1995;28(Suppl 2):80-90.

Parsons LH, Justice Jr JB. Perfusate serotonin increases extracellular dopamine in the nucleus accumbens as measured by in vivo microdialysis. Brain Res 1993;606:195-9.
Perry BD, Simon PR, U'Prichard DC. Interactions of neuroleptic compounds at alpha 2- adrenergic receptor affinity states in bovine caudate nucleus. Eur J Pharmacol 1983;95: 315-8.

Pompeiano M, Palacios JM, Mengod G. Distribution of the serotonin 5-HT2 receptor family mRNAs: comparison between 5 - $\mathrm{HT}_{2} \mathrm{~A}$ and 5-HT2C receptors. Brain Res Mol Brain Res 1994;23:163-78.

Remington G, Kapur S. Atypical antipsychotics: are some more atypical than others? Psychopharmacology (Berl) 2000;148:3-15.

Rosenblatt JS, Lehrman DS. Maternal behavior in the laboratory rat. In: Rheingold HL, editor. Maternal behavior in mammals. New York: John Wiley and Sons; 1963. p. 8-57. Safferman A, Lieberman JA, Kane JM, Szymanski S, Kinon B. Update on the clinical efficacy and side effects of clozapine. Schizophr Bull 1991;17:247-61.

Schmauss M,Wolff R, Erfurth A, Rüther E. Tolerability of long term clozapine treatment. Psychopharmacology (Berl) 1989;99(Suppl):S105-8.

Seeman P. Dopamine receptor sequences. Therapeutic levels of neuroleptics occupy D2 receptors, clozapine occupies D4. Neuropsychopharmacology 1992;7:261-84. Seeman P. Atypical antipsychotics: mechanism of action. Can J Psychiatry 2002;47: 27-38.

Seeman P, Lee T, Chau-Wong M, Wong K. Antipsychotic drug doses and neuroleptic/ dopamine receptors. Nature 1976;261:717-9.

Silva MR, Bernardi MM, Felicio LF. Effects of dopamine receptor antagonists on ongoing maternal behavior in rats. Pharmacol Biochem Behav 2001;68:461-8.

Silva MR, Bernardi MM, Cruz-Casallas PE, Felicio LF. Pimozide injections into the nucleus accumbens disrupt maternal behaviour in lactating rats. Pharmacol Toxicol 2003;93:42-7.

Stern JM, Keer SE. Maternal motivation of lactating rats is disrupted by low dosages of haloperidol. Behav Brain Res 1999;99:231-9.

Stern JM, Taylor LA. Haloperidol inhibits maternal retrieval and licking, but facilitates nursing behavior and milk ejection in lactating rats. J Neuroendocrinol 1991;3: 591-6.

Stolzenberg DS, McKenna JB, Keough S, Hancock R, Numan MJ, Numan $\mathrm{M}$. Dopamine D1 receptor stimulation of the nucleus accumbens or the medial preoptic area promotes the onset of maternal behavior in pregnancy-terminated rats. Behav Neurosci 2007;121:907-19.

Veiga CP, Miczek KA, Lucion AB, Almeida RM. Effect of 5 -HT1B receptor agonists injected into the prefrontal cortex on maternal aggression in rats. Braz J Med Biol Res 2007;40:825-30.

Whitaker NG, Lindstrom TD. Disposition and biotransformation of quinpirole, a new D-2 dopamine agonist antihypertensive agent, in mice, rats, dogs, and monkeys. Drug Metab Dispos 1987;15:107-13.

Wing LL, Tapson GS, Geyer MA. 5 HT-2 mediation of acute behavioral effects of hallucinogens in rats. Psychopharmacology (Berl) 1990;100:417-25.

Wright DE, Seroogy KB, Lundgren KH, Davis BM, Jennes L. Comparative localization of serotonin $\mathrm{A}, 1 \mathrm{C}$, and 2 receptor subtype mRNAs in rat brain. J Comp Neurol 1995;351: 357-73.

Zavitsanou K, Nguyen VH, Han M, Huang XF. Effects of typical and atypical antipsychotic drugs on rat brain muscarinic receptors. Neurochem Res 2007;32:525-32.

Zhao C, Li M. Sedation and disruption of maternal motivation underlie the disruptive effects of antipsychotic treatment on rat maternal behavior. Pharmacol Biochem Behav 2009;92:147-56. 